\title{
SUPPLEMENT TO THE \\ UMTRA PROJECT WATER SAMPLING AND ANALYSIS PLAN MEXICAN HAT, UTAH
}

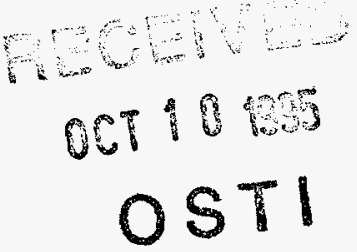

September 1995

\author{
Prepared for \\ U.S. Department of Energy \\ Environmental Restoration Division \\ UMTRA Project Team \\ Albuquerque, New Mexico \\ Prepared by \\ Jacobs Engineering Group Inc. \\ Albuquerque, New Mexico
}

\section{DISCLAIMER}

\begin{abstract}
This report was prepared as an account of work sponsored by an agency of the United States Government. Neither the United States Government nor any agency thereof, nor any of their employees, makes any warranty, express or implied, or assumes any legal liability or responsibility for the accuracy, completeness, or usefulness of any information, apparatus, product, or process disclosed, or represents that its use would not infringe privately owned rights. Reference herein to any specific commercial product, process, or service by trade name, trademark, manufacturer, or otherwise does not necessarily constitute or imply its endorsement, recommendation, or favoring by the United States Government or any agency thereof. The views and opinions of authors expressed herein do not necessarily state or reflect those of the United States Government or any agency thereof.
\end{abstract}




\section{DISCLAIMER}

Portions of this document may be illegible in electronic image products. Images are produced from the best available original document. 


\subsection{INTRODUCTION}

This water sampling and analysis plan (WSAP) supplement supports the regulatory and technical basis for water sampling at the Mexican Hat, Utah, Uranium Mill Tailings Remedial Action (UMTRA) Project site, as defined in the 1994 WSAP document for Mexican Hat (DOE, 1994). Further, the supplement serves to confirm our present understanding of the site relative to the hydrogeology and contaminant distribution as well as our intention to continue to use the sampling strategy as presented in the 1994 WSAP document for Mexican Hat.

\subsection{GROUND WATER AND SURFACE WATER MONITORING}

Ground water and surface water monitoring activities are derived from the U.S. Environmental Protection Agency regulations in 40 CFR Part 192 (1991) and 60 FR 2854 (1995). Sampling procedures are guided by the UMTRA Project standard operating procedures (JEG, n.d.), the Technical Approach Document (DOE, 1989), and the most effective technical approach for the site. Additional site-specific documents relevant to the Mexican Hat site are the Mexican Hat Long-Term Surveillance Plan (currently in progress), and the Mexican Hat Site Observational Work Plan (currently in progress).

\subsection{SAMPLING PLAN}

The sampling plan, as described in the 1994 WSAP, is to continue periodic (twice a year) monitoring of the site ground water monitoring wells and ground water seeps to continue to evaluate site characteristics and water quality as a result of the construction of the disposal cell. Sampling events are scheduled to occur during times representational of high ground water levels and low ground water levels. Over the next five years, it is expected that this sampling strategy will continue to be used to increase our understanding of the site. Because the seeps are hydraulically connected to the uppermost water-bearing unit, it is expected that data obtained by sampling these seeps will be used (in part) to evaluate changes over time with regards to cell compliance. The last sampling event occurred in April 1995, during a period of high ground water levels. The next scheduled sampling event is in November 1995, a time typically characterized by low ground water levels.

The following locations will be sampled at the Mexican Hat site in November 1995 and June 1996 (Figure 1):

- DOE monitor well 909.

- Ground water seeps in North Arroyo and Gypsum Creek: 249, 251, 255, 248, 254 , $261,922,923$, and 924 . 
The following constituents will be analyzed for: ammonium, calcium, chloride, gross alpha, gross beta, iron, manganese, molybdenum, nitrate, potassium, radium-226, radium-228, silica, sodium, strontium, sulfate, total dissolved solids (TDS), uranium, and vanadium. Field analyses will be conducted for alkalinity, dissolved oxygen, oxidation/reduction potential, $\mathrm{pH}$, specific conductance, and temperature.

\subsection{REFERENCES}

DOE (U.S. Department of Energy), 1994. UMTRA Project Water Sampling and Analysis Plan Mexican Hat, Utah, final, UMTRA-DOE/AL 62350-118, prepared by the U.S. Department of Energy, UMTRA Project Office, Albuquerque Operations Office, Albuquerque, New Mexico, April, 1994.

DOE (U.S. Department of Energy), 1989. Technical Approach Document, UMTRADOE/AL-050425.0002, prepared by the U.S. Department of Energy, UMTRA Project Office, Albuquerque Operations Office, Albuquerque, New Mexico.

JEG (Jacobs Engineering Group, Inc.), n.d. Albuquerque Operations Manual, standard operating procedures, prepared by Jacobs Engineering Group, Inc., Albuquerque, New Mexico, for the U.S. Department of Energy, UMTRA Project Office, Albuquerque Operations Office, Albuquerque, New Mexico.

\section{CODE OF FEDERAL REGULATIONS}

40 CFR Part 192, Health and Environmental Protection Standards for Uranium and Thorium Mill Tailings, U.S. Environmental Protection Agency (1991).

\section{FEDERAL REGISTER}

60 FR 2854, Groundwater Standards for Remedial Action at Inactive Uranium Processing Sites, Final Rule, U.S. Environmental Protection Agency, 11 January 1995. 


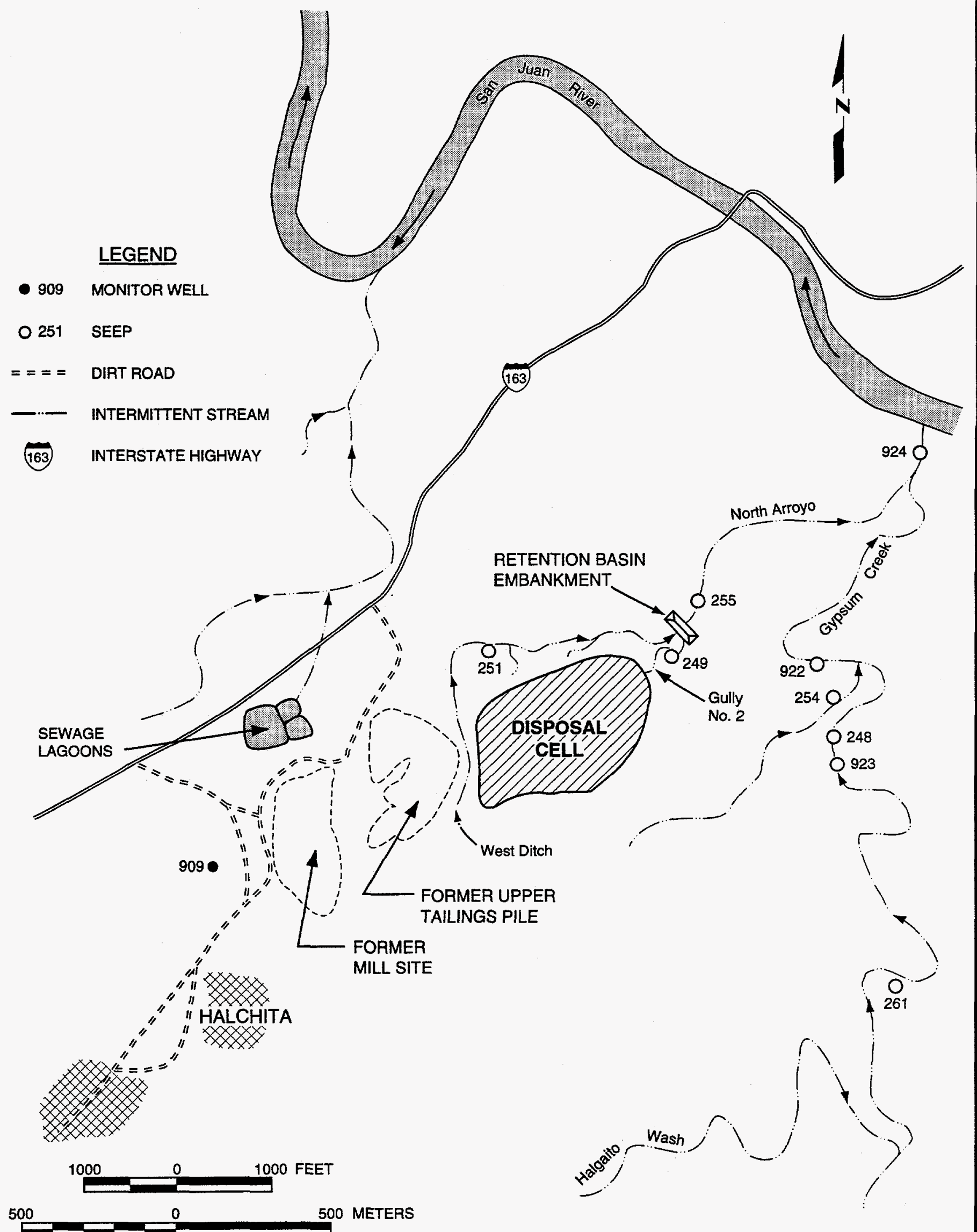

FIGURE 1 CURRENT CONFIGURATION OF THE MEXICAN HAT UMTRA PROJECT SITE 